\title{
Sulfate Transport in Normal and S-Deprived Chlorella fusca
}

\author{
Susanne Biedlingmaier and Ahlert Schmidt \\ Botanisches Institut, Tierärztliche Hochschule Hannover, Bünteweg 17d, \\ D-3000 Hannover 71, Bundesrepublik Deutschland \\ Z. Naturforsch. 44c, 495-503 (1989); received December 30, 1988 \\ Dedicated to Professor Achim Trebst on the occasion of his 60th birthday \\ Cation Stimulation, Chlorella fusca, Green Alga, Multiphasic Uptake, Sulfate Analogues, Sulfate \\ Starvation \\ Sulfate uptake into the unicellular green alga Chlorella fusca Shihira et Krauss strain 211-8b \\ was described as a $\mathrm{pH}$-, temperature- and energy-dependent process. Transport followed triphasic \\ kinetics with $K_{\mathrm{m}}$-values of $1.3 \times 10^{-5}, 3.9 \times 10^{-5}$ and $2.8 \times 10^{-4} \mathrm{M}$. The Hill plot showed coeffi- \\ cients of 1.0 for each uptake isotherm. Sulfate uptake was substantially inhibited by chromate, \\ selenate, sulfite, thiosulfate and tetrathionate. Cysteine and other mercaptides diminished sulfate \\ transport, whereas methionine was not inhibitory. Uptake was sensitive towards inhibitors of \\ photosynthesis and respiration and towards $\mathrm{SH}$-group reagents. Sulfate uptake could be strongly \\ enhanced by polyvalent cations, apparently via reduction of the surface potential. Sulfate uptake \\ in S-deprived algae was markedly different from constitutive sulfate uptake. Time kinetics was not \\ linear but showed an initial rapid phase. Uptake was neither multiphasic nor conformed to simple \\ Michaelis-Menten kinetics. Sulfate uptake was hardly affected by $\mathrm{pH}$ and temperature in the \\ suboptimal range. The Arrhenius plot was biphasic with a discontinuity at $38{ }^{\circ} \mathrm{C}$.
}

\section{Introduction}

Sulfur is an essential macroelement for algal nutrition, mainly available as sulfate in nature. Sulfate can be utilized as the only sulfur source, showing a rapid transformation to sulfur amino acids, sulfolipids and other S-containing substances. The first step in sulfate utilization is the uptake of the divalent anion into the cell. Sulfate uptake has been characterized in a variety of autotrophic organisms as an energy-dependent and highly specific process. In fungi and higher plant systems, sulfate transport was energized by a $3 \mathrm{H}^{+} /$sulfate cotransport mechanism, regulated by the intracellular sulfate pool $[1,2]$.

So far, only limited information is available for sulfate transport systems in green algae. Studies have been reported for the green alga Chlorella [3-6]. Due to the small quantities of sulfate assimilated by algae and plants, investigators often used "sulfate starvation conditions" to enhance sulfate transport and incorporation [5, 7-9]. Also the green alga

Abbreviations: CCCP, carbonylcyanide $m$-chlorophenylhydrazone; DCCD, N, N'-dicyclohexylcarbodiimide, DMBIB, 2,5-dibromo-3-methyl-6-isopropyl-p-benzochinon (dibromo-thymochinon); 2,4-DNP, 2,4-dinitrophenol; NEM, N-ethylmaleimide; PCMBS, $p$-chloromercuribenzylsulfonate.

Reprint requests to Prof. A. Schmidt.

Verlag der Zeitschrift für Naturforschung, D-7400 Tübingen 0341-0382/89/0500-0495 \$01.30/0
Chlorella fusca showed a marked increase of transport rates under sulfate limitation [10]. Sulfate transport rose tenfold after a lag period of $2.5 \mathrm{~h}$, strictly correlated with a depletion of the sulfate pool and the appearance of a sulfonate permease. Addition of external sulfate caused reversion of increased uptake and revealed a half-life of less than $1 \mathrm{~h}$ for the altered transport modus [11]. Both enhanced sulfate uptake and the appearance of a new sulfonate uptake system in Chlorella fusca were interpreted as specific responses to sulfate limitation [10].

Little is known, however, about the nature of this system for enhanced uptake and the differences between sulfate transport in normal and S-deprived organisms. The following study was initiated to characterize sulfate transport in Chlorella fusca under optimal and starvation-induced conditions. We will compare both uptake types and interpret them as a function of the internal sulfate pool.

\section{Materials and Methods}

\section{Organism}

Chlorella fusca Shihira et Krauss, strain 211-8b was obtained from the algal collection of Göttingen (F.R.G.) and cultured in the SL-1 ("sulfur-less") medium, pH 6.2: 5 mм $\mathrm{KNO}_{3}, 2 \mathrm{~mm} \mathrm{Mg}\left(\mathrm{NO}_{3}\right)_{2} \times 6$ $\mathrm{H}_{2} \mathrm{O}, 0.5 \mathrm{~mm} \mathrm{KH} \mathrm{PO}_{4}, 0.5 \mathrm{~mm} \mathrm{~K} \mathrm{HPO}_{4}, 0.25 \mathrm{~mm}$ $\mathrm{Ca}\left(\mathrm{NO}_{3}\right)_{2} \times 4 \mathrm{H}_{2} \mathrm{O}, 0.09 \mathrm{~mm}$ EDTA/ $\mathrm{FeCl}_{2}$ (each), 
$46 \mu \mathrm{M} \mathrm{H}_{3} \mathrm{BO}_{3}, 12.5 \mu \mathrm{M} \mathrm{Mn}\left(\mathrm{NO}_{3}\right)_{2} \times 4 \mathrm{H}_{2} \mathrm{O}, 0.73 \mu \mathrm{M}$ $\begin{array}{lllllll}\mathrm{ZnCl}_{2}, & 0.31 & \mu \mathrm{M} & \mathrm{Cu}\left(\mathrm{NO}_{3}\right)_{2} \times 3 & \mathrm{H}_{2} \mathrm{O}, & 0.089 & \mu \mathrm{M}\end{array}$ $\mathrm{Na}_{2} \mathrm{MoO}_{4} \times 2 \quad \mathrm{H}_{2} \mathrm{O}$. For exponential growth the medium contained $0.3 \mathrm{~mm}$ sodium sulfate. For sulfate starvation conditions $\mathrm{Na}_{2} \mathrm{SO}_{4}$ was omitted and in some experiments replaced by ethanesulfonate $(0.3 \mathrm{~mm})$, a sulfur compound that allows growth under conditions of sulfate starvation [10]. The algae were grown in a Kniese apparatus at $27^{\circ} \mathrm{C}$, continuous light, and a fluence rate of $90 \mu \mathrm{mol} \mathrm{m} \mathrm{m}^{-2} \mathrm{~s}^{-1}$ (type Osram L-Interna $40 \mathrm{~W}-39 \mathrm{c}) .750 \mathrm{ml}$ cultures were run without synchronization in 11 flasks $(\varnothing=65 \mathrm{~mm})$ and gassed with normal air. The cultures were started with a $0.1 \mathrm{ml}$ inoculum of Chlorella stock cultures $\left(6 \times 10^{6}\right.$ cells $)$ to minimize the carry over of sulfur compounds. Algal cells were harvested in the exponential growth phase usually $4-5$ days after inoculation, S-starved algae were grown for 5 days.

\section{Uptake assays}

Cultures were harvested by centrifugation $(5 \mathrm{~min}$ at $5000 \times g$ ), washed in sulfur-free medium and resuspended to a density of $1-2 \times 10^{8}$ cells $\mathrm{ml}^{-1}$ in $2 \mathrm{ml}$ of SL-1 medium, pH 6.2. The experiments were started by addition of $\left[{ }^{35} \mathrm{~S}\right]$ sulfate to a final concentration of $0.3 \mathrm{~mm}$ and a specific radioactivity of $65 \mathrm{kBq} \mathrm{nmol}{ }^{-1}$. Algae were incubated for 5 to $90 \mathrm{~min}$ at $27^{\circ} \mathrm{C}$ in a Warburg vessel using a "Warburg" apparatus illuminated with Riva D1 lamps and a fluence rate of $240 \mu \mathrm{mol} \mathrm{m} \mathrm{m}^{-2} \mathrm{~s}^{-1}$ (400 to $800 \mathrm{~nm}$ range). Samples were washed several times by centrifugation and resuspension in S-free medium. The radioactivity accumulated was determined in a liquid scintillation counter and corrected for unspecific adsorption, determined from previously heat-killed cells. Chemicals and equipment ${ }^{35} \mathrm{~S}$-labeled carrierfree sulfate was obtained from Amersham-Buchler (Braunschweig, W. Germany). All other chemicals were purchased as described earlier [12]. The Kniese apparatus for algal cultivation was purchased from Kniese (Marburg, W. Germany).

\section{Results}

\section{A) Characterization of the constitutive sulfate uptake in Chlorella fusca}

Linearity of sulfate uptake: time course and cell density

Sulfate uptake at $0.3 \mathrm{~mm}$ was linear with respect to time for up to $90 \mathrm{~min}$ of incubation at $28^{\circ} \mathrm{C}$. Sulfate uptake was directly proportional to cell density up to $3 \times 10^{8}$ cells $\mathrm{ml}^{-1}$ in the assay. Cell densities of $1-2 \times 10^{8}$ cells $\mathrm{ml}^{-1}$ were used for all subsequent uptake studies.

Effect of $\mathrm{pH}$ and temperature on sulfate uptake

Both $\mathrm{pH}$ and temperature had a pronounced effect on constitutive sulfate uptake in Chlorella fusca (Fig. 1,2). A pH of 9.0 was optimal using $0.01 \mathrm{~m} \mathrm{Tris} / \mathrm{HCl}$ buffer, $\mathrm{pH} 7.0-10.5$ during incubation. In $0.01 \mathrm{M}$ $\mathrm{KH}_{2} \mathrm{PO}_{4} / \mathrm{K}_{2} \mathrm{HPO}_{4}$ buffer, $\mathrm{pH}$ 5.0-8.5 sulfate transport was maximal at $\mathrm{pH} 8.5$ and declined rapidly at lower $\mathrm{pH}$-values confirming an unusually high $\mathrm{pH}$ optimum.

The temperature optimum of sulfate uptake was about $43^{\circ} \mathrm{C}$ (Fig. 2). At higher temperatures sulfate uptake decreased strongly, strongly, and transport was completely inactivated after short preincubation above $55^{\circ} \mathrm{C}$. The $\mathrm{Q}_{10}$ decreased from 2.0 between $18^{\circ} \mathrm{C}$ and $33{ }^{\circ} \mathrm{C}$ to 1.7 between $33^{\circ} \mathrm{C}$ and $43{ }^{\circ} \mathrm{C}$. From the Arrhenius plot an approximate activation energy of $49.1 \mathrm{~kJ} \mathrm{~mol}^{-1}$ between $18{ }^{\circ} \mathrm{C}$ and $43{ }^{\circ} \mathrm{C}$ was calculated. The Arrhenius plot was monophasic over the whole temperature range tested, indicating that

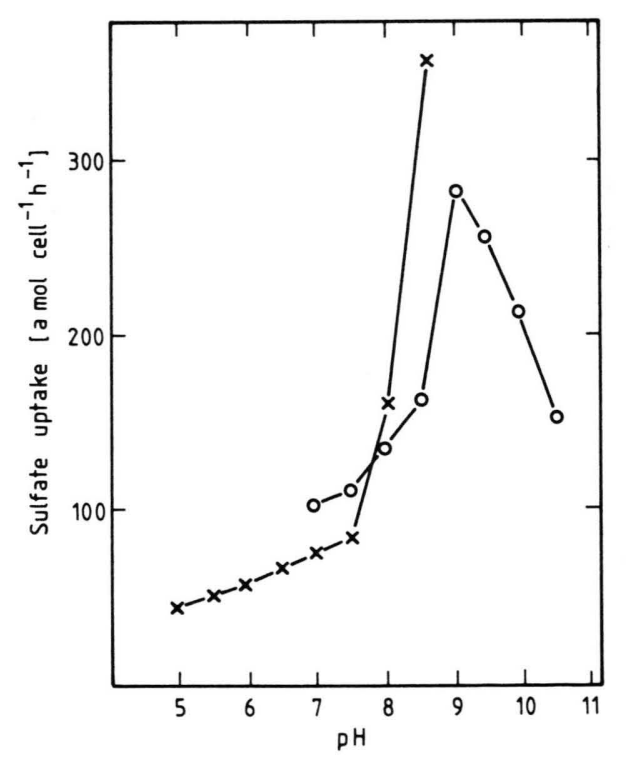

Fig. 1. pH-dependence of constitutive sulfate uptake. Sulfate-grown algae were washed and incubated in $0.01 \mathrm{~m}$ $\mathrm{KH}_{2} \mathrm{PO}_{4} / \mathrm{K}_{2} \mathrm{HPO}_{4}$ buffer ( $\mathrm{pH} 5.0-8.5$ ) or in $0.01 \mathrm{M}$ Tris$\mathrm{HCl}$ buffer (pH 7.0-10.5). Uptake period $30 \mathrm{~min}$. Average of three replicates; average SE $9.0 \% . \times \longrightarrow \times=$ phosphate buffer; $\mathrm{O} \longrightarrow \mathrm{O}=$ Tris- $\mathrm{HCl}$ buffer. 


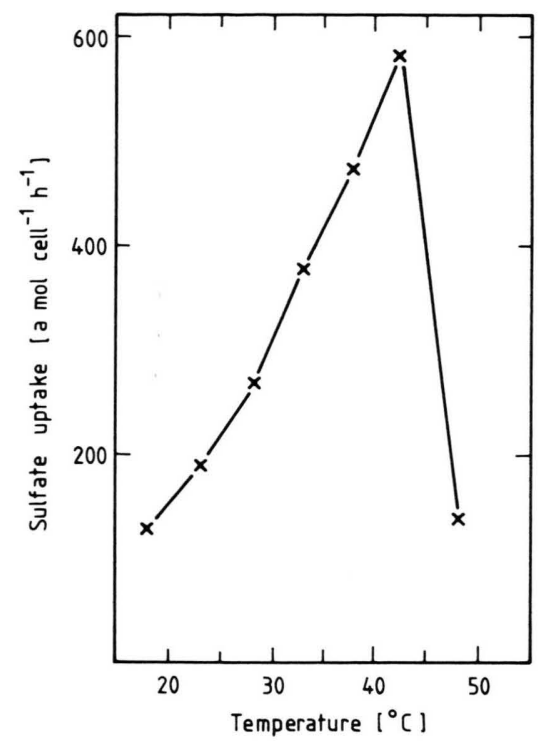

Fig. 2. Temperature dependence of constitutive sulfate uptake. Washed sulfate-grown algae were suspended in the prewarmed S-free medium and assayed for sulfate uptake after $15 \mathrm{~min}$ incubation. Average of three replicates; average SE $12.1 \%$.

membranous transition had occurred at lower temperature $\left(13^{\circ} \mathrm{C}[13]\right)$.

Concentration dependence of sulfate uptake

The rate of sulfate uptake was determined in the concentration range from $10^{-6} \mathrm{M}$ to $10^{-2} \mathrm{M}$ (Fig. 3).

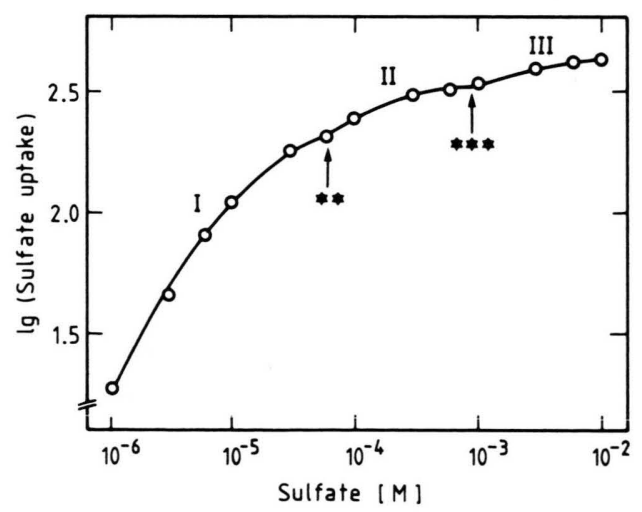

Fig. 3. Concentration dependence of constitutive sulfate uptake. Uptake period $30 \mathrm{~min}$. Data are expressed as amol cell $^{-1} 30 \mathrm{~min}^{-1}$. Average of three replicates; average SE $8 \%$. The roman numerals represent isotherm sections designated in Table $\mathrm{I} ;{ }^{* *},{ }^{* * *}$ refer to transition points.

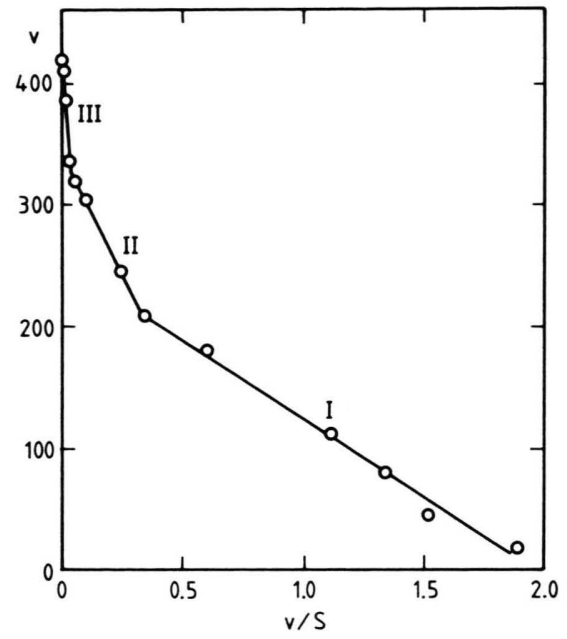

Fig. 4. Eadie-Hofstee plot of sulfate uptake using the data of Fig. 3. Sulfate concentration is given in $\mu$ m.

The Eadie-Hofstee plot (Fig. 4) showed a triphasic response with $K_{\mathrm{m}}$-values in increasing order:

Phase I $\left(1 \times 10^{-6} \mathrm{M}\right.$ to $\left.6 \times 10^{-5} \mathrm{M}\right): K_{\mathrm{m}}=1.3 \times 10^{-5} \mathrm{M}$ Phase II $\left(6 \times 10^{-5} \mathrm{M}\right.$ to $\left.9 \times 10^{-4} \mathrm{M}\right): K_{\mathrm{m}}=3.9 \times 10^{-5} \mathrm{M}$ Phase III $\left(9 \times 10^{-4} \mathrm{M}\right.$ to $\left.1 \times 10^{-2} \mathrm{M}\right): K_{\mathrm{m}}=2.8 \times 10^{-4} \mathrm{M}$

Thus, sulfate uptake in the alga Chlorella fusca appeared to be multiphasic as in higher plants [14, 15]. Sulfate transport can be described by a single, multiphasic isotherm having three phases. Each phase covered a limited concentration range, obeyed Michaelis-Menten kinetics and was separated from adjacent phases by sharp transition points (see Table I). The uptake data of Fig. 4 and 5 were analyzed

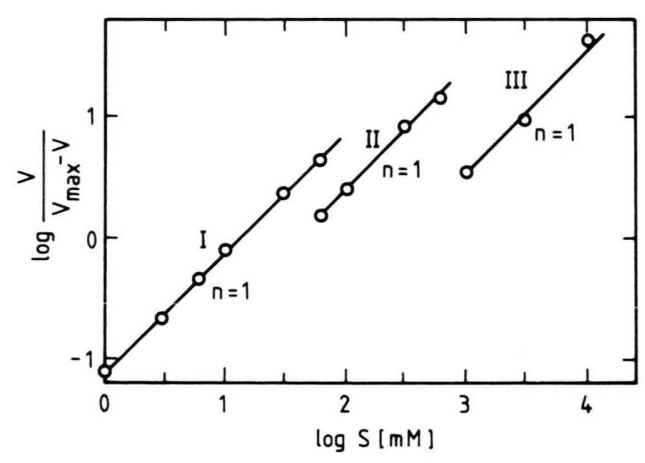

Fig. 5. Hill plot of sulfate uptake as a function of sulfate concentration using the data of Fig. 3. The roman numerals refer to isotherm sections designated in Table I. 
Table I. Kinetic constants and transition points for sulfate uptake in Chlorella fusca. Calculation according to data presented in Fig. 3 and $4 ;^{* *},{ }^{* * *}$ refers to transition points.

\begin{tabular}{llll}
\hline $\begin{array}{l}\text { Phase } \\
V_{\max } \\
{[\mathrm{amol} \mathrm{cell}}\end{array}$ & $\begin{array}{l}K_{\mathrm{m}} \\
{[\mathrm{M}]}\end{array}$ & $\begin{array}{l}\text { Transition } \\
{[\mathrm{M}]}\end{array}$ \\
\hline I & $252 \pm 9$ & $(13 \pm 1) \times 10^{-4}$ & \\
II & $339 \pm 4$ & $(39 \pm 2) \times 10^{-4}$ & $6.0 \times 10^{-5}$ (chosen) $^{* *}$ \\
III & $426 \pm 6$ & $(28 \pm 3) \times 10^{-3}$ & $9.2 \times 10^{-4}{\text { (calc. })^{* * *}}^{-1} \pm 6$ \\
\hline
\end{tabular}

for cooperativity using the following Hill equation (Fig. 5):

$$
\log \left(V / V_{\max }-V\right)=n \log S-K_{\mathrm{m}} .
$$

Each phase has a single slope and Hill coefficients of 1.0 .

Substrate specificity of sulfate uptake

The specificity of the sulfate uptake system was tested by competition experiments using various group VI anions of the type $\mathrm{XO}_{4}{ }^{2-}$ (Table II). Greatest inhibition was observed by chromate, where $3 \mathrm{~mm}$ resulted in $90 \%$ inhibition and $0.03 \mathrm{~mm}$ in $55 \%$ inhibition. Selenate, which is a distinctly larger anion than sulfate, diminished transport processes with increasing concentrations and caused $74 \%$ inhibition at $3 \mathrm{~mm}$. Little inhibition of sulfate transport was observed in the presence of molybdate or tungstate. $3 \mathrm{~mm}$ sulfate itself decreased uptake to about $15 \%$ according to isotopic dilution (Table II).

Obviously the alga Chlorella fusca could not discriminate among anions of type $\mathrm{XO}_{4}{ }^{2-}$ except by the different molecule size itself. Thus, only chromate and selenate compete for sulfate uptake, whereas the significantly larger anions, molybdate and tungstate, do not affect sulfate transport.

Sulfate uptake was further inhibited by thiosulfate and by tetrathionate and its analogue sulfite, using a 10 -fold higher concentration as compared to sulfate (Table II). The existence of specific recognition sites for sulfate attachment was further demonstrated by the failure of the monovalent anions chloride, nitrate, methanesulfonate and ethanesulfonate to affect sulfate transport negatively. Also phosphate did not influence sulfate influx in Chlorella fusca.

Finally the effects of cysteine, methionine and other SH-containing compounds were studied. Both amino acids are known as end products of sulfur
Table II. Effect of structural analogues and other compounds on sulfate uptake. Washed algae were preincubated for $5 \mathrm{~min}$ in the presence of the unlabeled test substance (3 $\mathrm{mm})$ before adding $\left[{ }^{35} \mathrm{~S}\right]$ sulfate to the incubation medium. Uptake period $30 \mathrm{~min}$. All compounds were used as sodium salts, except the amino acids and mercaptenes. Control: 620 amol cell ${ }^{-1} \mathrm{~h}^{-1}$. Averages $\pm \operatorname{SD}(n=3)$.

\begin{tabular}{|c|c|}
\hline $\begin{array}{l}\text { Compound } \\
{[3 \mathrm{~mm}]}\end{array}$ & $\begin{array}{l}\text { Sulfate uptake } \\
\text { [\% of control] }\end{array}$ \\
\hline None & 100 \\
\hline $\begin{array}{l}\text { Sulfate } \\
\text { Sulfite } \\
\text { Thiosulfate } \\
\text { Tetrathionate }\end{array}$ & $\begin{array}{l}15 \pm 2 \\
34 \pm 3 \\
25 \pm 2 \\
31 \pm 3\end{array}$ \\
\hline $\begin{array}{l}\text { Nitrate } \\
\text { Chloride } \\
\text { Ethanesulfonate } \\
\text { Methanesulfonate } \\
\text { Phosphate }\end{array}$ & $\begin{array}{r}98 \pm 4 \\
115 \pm 5 \\
100 \pm 4 \\
103 \pm 4 \\
104 \pm 5\end{array}$ \\
\hline $\begin{array}{l}\text { Cysteine } \\
\text { Methionine } \\
\text { Mercaptoethanol } \\
\text { Cysteamine } \\
\text { Dithioerythritol }\end{array}$ & $\begin{array}{r}65 \pm 3 \\
108 \pm 4 \\
80 \pm 5 \\
65 \pm 4 \\
37 \pm 4\end{array}$ \\
\hline $\begin{array}{ll}\text { Chromate } & 0.03 \mathrm{~mm} \\
& 0.3 \mathrm{~mm} \\
& 3.0 \mathrm{~mm}\end{array}$ & $\begin{array}{l}45 \pm 5 \\
22 \pm 5 \\
10 \pm 2\end{array}$ \\
\hline $\begin{array}{ll}\text { Selenate } & 0.03 \mathrm{~mm} \\
& 0.3 \mathrm{~mm} \\
& 3.0 \mathrm{~mm}\end{array}$ & $\begin{array}{l}90 \pm 8 \\
53 \pm 6 \\
26 \pm 4\end{array}$ \\
\hline $\begin{array}{lll}\text { Molybdate } & 0.03 \mathrm{~mm} \\
& 0.3 \mathrm{~mm} \\
& 3.0 \mathrm{~mm}\end{array}$ & $\begin{array}{r}102 \pm 6 \\
101 \pm 6 \\
85 \pm 4\end{array}$ \\
\hline $\begin{array}{r}\text { Tungstate } 0.03 \mathrm{~mm} \\
0.3 \mathrm{~mm} \\
3.0 \mathrm{~mm}\end{array}$ & $\begin{array}{r}102 \pm 10 \\
100 \pm 5 \\
97 \pm 5\end{array}$ \\
\hline
\end{tabular}

metabolism. Whereas methionine did not inibit sulfate transport, cysteine diminished transport rates to $65 \%$ of the control value, comparable to the influence of other SH-compounds on this uptake system. 
Table III. Effect of various inhibitors on sulfate uptake. Washed algae were preincubated for $5 \mathrm{~min}$ in the incubation medium containing each compound in the concentration indicated. After adding $\left[{ }^{35} \mathrm{~S}\right]$ sulfate, the Warburg vessels were incubated for $30 \mathrm{~min}$. Substances marked with * were solubilized in ethanol and referred to the ethanol control. Control: 602 amol cell ${ }^{-1} \mathrm{~h}^{-1}$. Averages $\pm \operatorname{SD}(n=3)$.

\begin{tabular}{lcr}
\hline Inhibitor & $\begin{array}{c}\text { Concn. } \\
{[\mathrm{mm}]}\end{array}$ & $\begin{array}{r}\text { Sulfate uptake } \\
{[\% \text { of control) }}\end{array}$ \\
\hline None & \multicolumn{2}{c}{100} \\
Sodium fluoride & 1.0 & $125 \pm 9$ \\
Sodium iodoacetate & 1.0 & $150 \pm 11$ \\
Sodium cyanide & 1.0 & $62 \pm 6$ \\
Sodium azide & 1.0 & $67 \pm 6$ \\
DCMU* & 1.0 & $45 \pm 6$ \\
"Darkness" & & $51 \pm 5$ \\
Dibromothymochinon* & 0.01 & $124 \pm 7$ \\
& 0.1 & $84 \pm 6$ \\
& 1.0 & 0 \\
2,4-DNP* & 1.0 & $39 \pm 4$ \\
CCCP* & 0.01 & $20 \pm 3$ \\
& 0.1 & 0 \\
DCCD* & 1.0 & 0 \\
& 0.01 & $72 \pm 7$ \\
& 0.1 & $27 \pm 3$ \\
NEM* & 1.0 & $13 \pm 4$ \\
PCMBS & 1.0 & $36 \pm 3$ \\
Ethanol (1\%) & 1.0 & $125 \pm 9$ \\
\hline
\end{tabular}

Effect of various inhibitors on sulfate uptake

Several metabolic inhibitors were tested for their effects on sulfate uptake (Table III). Sulfate uptake was not diminished by inhibitors of glycolysis (fluoride, iodoacetate), both compounds even increased sulfate transport. Inhibitors of photosynthesis and respiration (cyanide, azide, DCMU and DMBIB) decreased uptake markedly. "Darkness" reduced sulfate uptake to $50 \%$ of the light control. The uncouplers 2,4-DNP and CCCP showed substantial inhibition; also the ATPase inhibitor DCCD decreased transport rates. The sulfhydryl group reagent $\mathrm{N}$-ethylmaleimide reduced transport significantly, whereas the non-penetrating thiol reagent PCMBS failed to affect sulfate uptake, excluding the interaction of outer-membrane sulfhydryl groups in the transport process. Ethanol, used to solubilize certain inhibitors, had no effect.
Effect of various cations on sulfate uptake

Most of the metal ions tested had pronounced effects on sulfate uptake (Table IV); especially di- and trivalent cations stimulated uptake 2-3-fold. Although Chlorella fusca showed uptake rates already in $1 \mathrm{~mm}$ phosphate buffer, divalent cations $\left(\mathrm{Mg}^{2+}\right.$, $\left.\mathrm{Ca}^{2+}, \mathrm{Mn}^{2+}, \mathrm{Fe}^{2+}, \mathrm{Zn}^{2+}, \mathrm{Cd}^{2+}, \mathrm{Cu}^{2+}\right)$ and trivalent ions $\left(\mathrm{Fe}^{3+}, \mathrm{Al}^{3+}\right)$ enhanced transport of sulfate markedly. Nearly identical effects were observed with all divalent and trivalent cations tested, whereas their anions were interchangeable. Monovalent cations $\left(\mathrm{Li}^{+}, \mathrm{Na}^{+}, \mathrm{K}^{+}\right)$had no positive effect on sulfate uptake; $\mathrm{Hg}^{2+}$ was inhibitory, probably due to interference with SH-groups.

\section{B) Characterization of the enhanced sulfate uptake under sulfate limitation}

Time course

Whereas constitutive sulfate uptake was linear in time up to $90 \mathrm{~min}$ incubation, sulfate transport in Sstarved cultures followed an unusual pattern (Fig. 6). The initial rate of uptake was very rapid and reached a maximum in less than $7.5 \mathrm{~min}$. This initial rapid uptake was followed by a slow but linear uptake over the next $1 \mathrm{~h}$ ("steady-state rate").

Table IV. Effect of various cations on sulfate uptake. Washed algae were preincubated for $5 \mathrm{~min}$ in the $3 \mathrm{~mm}$ concentrated compound before adding $\left[{ }^{35} \mathrm{~S}\right]$ sulfate to $1 \mathrm{~mm}$ $\mathrm{KH}_{2} \mathrm{PO}_{4} / \mathrm{K}_{2} \mathrm{HPO}_{4}$ buffer ( $\mathrm{pH} 7.5$ ). Uptake period $30 \mathrm{~min}$. Cations were used as the chloride salts; data are not corrected for possible phosphate complexes. Control: 590 amol cell ${ }^{-1} \mathrm{~h}^{-1}$. Averages $\pm \mathrm{SD}(n=3)$.

\begin{tabular}{ll}
\hline $\begin{array}{l}\text { Cations } \\
{[3 \mathrm{~mm}]}\end{array}$ & $\begin{array}{l}\text { Sulfate uptake } \\
{[\% \text { of control] }}\end{array}$ \\
\hline $\mathrm{None}$ & 100 \\
$\mathrm{Li}^{+}$ & $100 \pm 5$ \\
$\mathrm{Na}^{+}$ & $98 \pm 4$ \\
$\mathrm{~K}^{+}$ & $100 \pm 5$ \\
$\mathrm{Mg}^{2+}$ & $180 \pm 17$ \\
$\mathrm{Ca}^{2+}$ & $194 \pm 14$ \\
$\mathrm{Ba}^{2+}$ & $680 \pm 157$ \\
$\mathrm{Mn}^{2+}$ & $200 \pm 13$ \\
$\mathrm{Fe}^{2+}$ & $188 \pm 29$ \\
$\mathrm{Zn}^{2+}$ & $196 \pm 19$ \\
$\mathrm{Cd}^{2+}$ & $170 \pm 17$ \\
$\mathrm{Cu}^{2+}$ & $152 \pm 10$ \\
$\mathrm{Hg}^{2+}$ & $2 \pm 1$ \\
$\mathrm{Fe}^{3+}$ & $215 \pm 24$ \\
$\mathrm{Al}^{3+}$ & $225 \pm 35$ \\
\hline
\end{tabular}




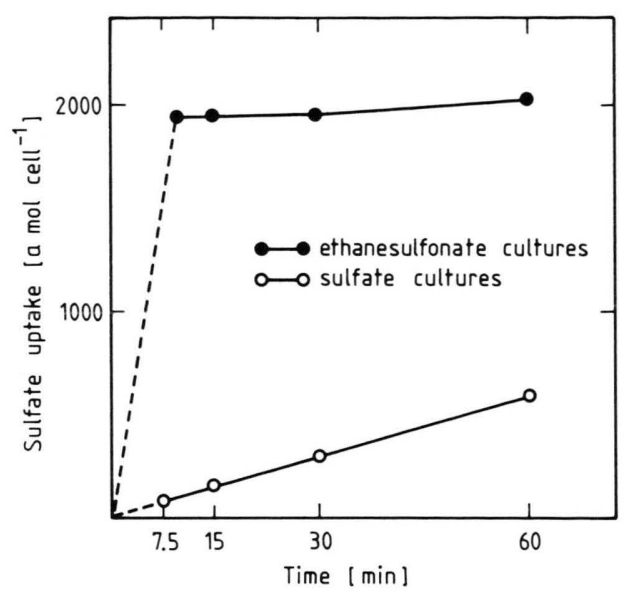

Fig. 6. Time dependence of enhanced sulfate uptake. Algae were grown for 5 days on $0.3 \mathrm{~mm}$ ethanesulfonate. For comparison the data for sulfate uptake in sulfate medium are included. Average of three replicates; average SE $14.6 \%$.

Kinetics of enhanced sulfate uptake

The rate of sulfate uptake was determined in the concentration range from $1 \times 10^{-7}$ to $3 \times 10^{-4} \mathrm{M}$. No typical Michaelis-Menten hyperbolic curve was obtained plotting uptake velocity versus substrate concentration and no meaningful kinetic constants were obtained when the data were expressed in classical reciprocal plots. Comparing the concentration dependence of sulfate uptake in normal and sulfate starved cultures showed a clear separation point (critical concentration) around $0.01 \mathrm{~mm}$ sulfate (Fig. 7). At concentrations below $0.01 \mathrm{~mm}$ both uptake velocities were nearly identical and straight lines with similar $K_{\mathrm{m}}$-values each were obtained using the Lineweaver-Burk plot. A $K_{\mathrm{m}}$-value of $1.0 \times 10^{-5} \mathrm{M}$ for sulfate uptake could be determined (data not shown), comparable to the $K_{\mathrm{m}}$ of phase 1 for constitutive sulfate uptake (Table I).

At concentrations above $0.01 \mathrm{~mm}$, sulfate uptake in S-starved cultures showed exceeding transport rates (Fig. 7), and the reciprocal plot revealed a concave upwards curve with negative values for $K_{\mathrm{m}}$ and $V_{\max }$. Thus, data obtained at higher sulfate concentrations cannot be interpreted in terms of classical Michaelis-Menten kinetics. They must be composed of 2 or more kinetic systems as known from other transport processes in which an enhanced early uptake contributed significantly to total uptake [16].

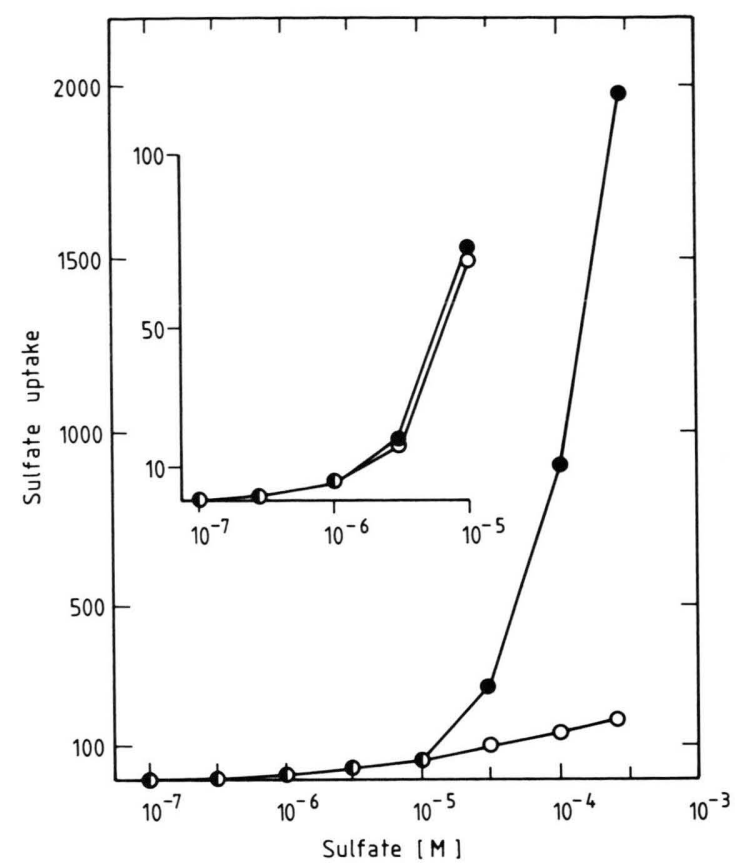

Fig. 7. Concentration dependence of enhanced sulfate uptake in S-starved algae in comparison to constitutive uptake in non-starved cultures. Uptake period $15 \mathrm{~min}$. Average of two replicates; average SE $12.8 \%$. $\bigcirc-\bigcirc=$ sulfate culture; = ethanesulfonate culture.

Effect of $\mathrm{pH}$ on enhanced sulfate uptake

Sulfate uptake in starved cultures was hardly affected by the $\mathrm{pH}$ in the range of $\mathrm{pH} 5.0-9.0$ (Fig. 8). A slight optimum around $\mathrm{pH} 9.0$ might be seen in accordance with constitutive sulfate uptake in this alga (compare Fig. 1).

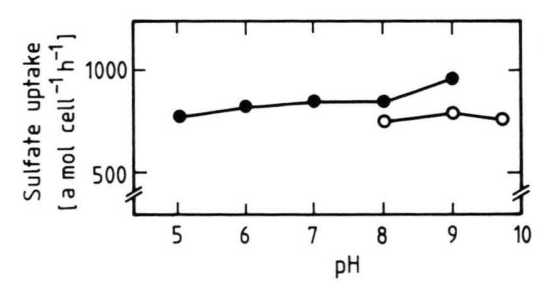

Fig. 8. pH-dependence of enhanced sulfate uptake. Ethanesulfonate grown algae were incubated in $0.01 \mathrm{~m}$ $\mathrm{KH}_{2} \mathrm{PO}_{4} / \mathrm{K}_{2} \mathrm{HPO}_{4}$ buffer ( $\mathrm{pH} 5.0-9.0$ ) or in $0.01 \mathrm{Tris} / \mathrm{HCl}$ buffer ( $\mathrm{pH} 8.0-10.0$ ). Uptake period $30 \mathrm{~min}$. Average of two replicates; average SE $5.9 \%$. -0 phosphate buffer; $\mathrm{O} \bigcirc \mathrm{O}=$ Tris- $\mathrm{HCl}$ buffer. 


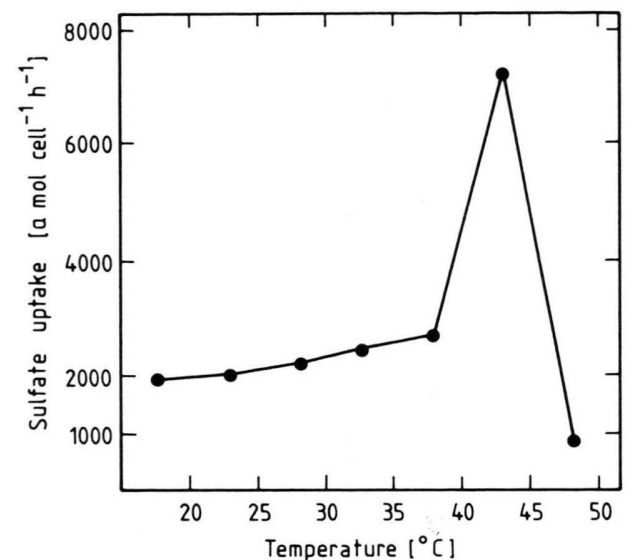

Fig. 9. Temperature dependence of enhanced sulfate uptake. Ethanesulfonate grown algae were suspended in prewarmed S-free medium and assayed for sulfate uptake after $15 \mathrm{~min}$ incubation. Average of two replicates; average SE $11.0 \%$.

Effect of temperature on enhanced sulfate uptake

The temperature optimum of $43{ }^{\circ} \mathrm{C}$ was wellmarked (Fig. 9) and identical to the value determined in sulfate-grown cultures. The temperature dependence was greatly reduced to a $\mathrm{Q}_{10}$ of 1.2 between $18{ }^{\circ} \mathrm{C}$ and $38{ }^{\circ} \mathrm{C}$, whereas the $\mathrm{Q}_{10}$ rose to 2.7 between $33{ }^{\circ} \mathrm{C}$ and $43{ }^{\circ} \mathrm{C}$. The Arrhenius plot from $18{ }^{\circ} \mathrm{C}$ to $43{ }^{\circ} \mathrm{C}$ was biphasic with a discontinuity at $38^{\circ} \mathrm{C}$ (Fig. 10). Both activation energies were calculated to $15.1 \mathrm{~kJ} / \mathrm{mol}$ between $18-38^{\circ} \mathrm{C}$ and to $163.0 \mathrm{~kJ} / \mathrm{mol}$ above $38^{\circ} \mathrm{C}$. Arrhenius plots with an upward bend are unusual, since activation energies normally decrease at higher temperatures.

Substrate specificity of enhanced sulfate uptake

The specificity of the sulfate uptake system(s) involved was tested by competition experiments using group IV anions of the type $\mathrm{XO}_{4}{ }^{2-}$ in a tenfold concentration as compared to sulfate. Inhibition of these analogues was comparable to their effects on constitutive sulfate uptake.

\section{Discussion}

The freshwater organism Chlorella fusca was grown under adequate mineral nutrition to avoid physiological side effects on sulfate uptake by starvation. These conditions were used to characterize sulfate transport as an active, multiphasic process with

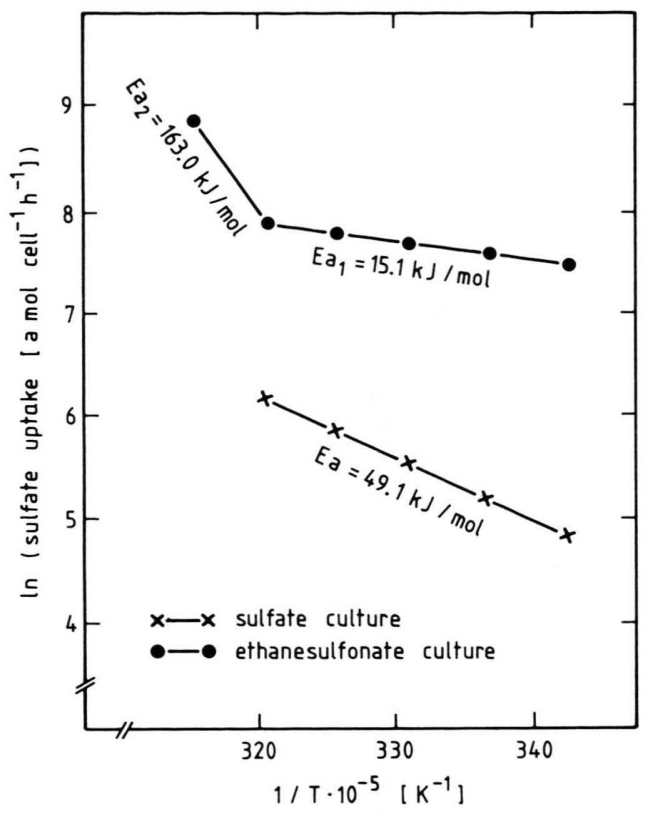

Fig. 10. Arrhenius plot of constitutive and enhanced sulfate uptake. The data of Fig. 2 and 9 were used.

optima of $43{ }^{\circ} \mathrm{C}$ and $\mathrm{pH} 9.0$ and a specificity for anions of the type $\mathrm{XO}_{4}{ }^{2-}$ (part A).

Sulfate transport in non-deprived Chlorella fusca was multiphasic as in higher plant systems. Multiphasic uptake has been reported for roots and leaves of barley and for a variety of other plants $[14,17]$. Singh and Paul [18] observed tetraphasic uptake of sulfate in excised maize roots, Shargool and Ngo [19] found biphasic uptake in excised roots of rape seedlings; whereas Jones and Smith [20] observed monophasic sulfate uptake into cultured tobacco cells. Also Fucus serratus showed a monophasic response to external sulfate in the concentration range $10^{-6} \mathrm{M}$ to $10^{-2} \mathrm{M}$ [7].

In the case of Chlorella fusca, sulfate uptake could be described by a single multiphasic isotherm having three phases. Each phase covered a limited concentration range and obeyed Michaelis-Menten kinetics (see [14]). The $K_{\mathrm{m}}$ of phase I $1.3 \times 10^{-5} \mathrm{M}$ and phase II $3.9 \times 10^{-5} \mathrm{M}$ were relatively high compared to other freshwater organism, e.g. Chlorella pyrenoidosa $1.2 \times 10^{-6}$ м [5], Synechococcus $63017.5 \times 10^{-7}$ [21] or Spirulina platensis $1 \times 10^{-7}$ м [22]. However, sulfate concentrations in freshwater have been reported as $0.11-0.18 \mathrm{~mm}$ [23]; thus the $K_{\mathrm{m}}$ of phase II 
$3.9 \times 10^{-5} \mathrm{M}$ is sufficient to allow adequate nutrition with sulfate.

Sulfate transport was highly dependent on temperature and $\mathrm{pH}$ in the assay, although sulfate represents a divalent anion throughout the whole range tested. The temperature optimum was about $43{ }^{\circ} \mathrm{C}$; this value is markedly above the temperature tolerance of this strain. However, uptake of uracil and guanine in Chlorella fusca was also optimal around $40{ }^{\circ} \mathrm{C}[13,24]$. The activation energy between $18^{\circ} \mathrm{C}$ and $43{ }^{\circ} \mathrm{C}$ was $49.1 \mathrm{~kJ} \mathrm{~mol}^{-1}$, calculated by an Arrhenius plot for Chlorella fusca. This value seems to be related to the double negative charge involved, since the activation energy for uptake of electroneutral guanine is $35.5 \mathrm{~kJ} \mathrm{~mol}^{-1}$ [13], and the activation energy for uptake of the monovalent ethanesulfonate was $41.3 \mathrm{~kJ} \mathrm{~mol}^{-1}$ [12].

The pH-optimum of 9.0 for sulfate uptake in Chlorella fusca is similar to that of cyanobacteria [21, $22,25]$, but unusually high compared with fungi or higher plants $[2,26,27]$. It may be adapted to the natural conditions of the environment, since Chlorella fusca is tolerant to $\mathrm{pH}$-values between 3.5 and 10.5 during cultivation.

The high $\mathrm{pH}$-optimum and the relatively low membrane potential of $-46 \mathrm{mV}$ in Chlorella fusca [28] do not support the idea of sulfate uptake via simple proton cotransport. Sulfate transport was further enhanced in the presence of divalent or trivalent cations in the medium found also for ethanesulfonate uptake in the same alga [12] and for sulfate uptake in fungi $[2,26]$. Polyvalent cations could enhance uptake of anions via reduction of the surface potential [2], thus favouring the accumulation of anions at the binding site. However, one clear difference between Chlorella fusca and the fungal systems was obvious: None of the Aspergillus or Penicillium strains tested transported sulfate at measurable rates in the absence of polyvalent cations, whereas Chlorella fusca was able to do so $[2,26]$. The "stimulatory" effect of $\mathrm{Ba}^{2+}$ was probably due to precipitation of $\mathrm{Ba}-\left[{ }^{35} \mathrm{~S}\right]$ sulfate on the algal surface rather than to effects via surface potential, membrane potential or cell $\mathrm{pH}$.

Sulfate uptake in Chlorella fusca is an energyrequiring process, as shown by the negative effects of various metabolic inhibitors (cyanide, azide, DCMU, DMBIB, CCCP, DCCD) and darkness. Sulfate uptake is active and occurs against a concentration gradient since the concentration of sulfate obtained by diffusion should not exceed $0.008 \mathrm{~mm}$ (see
Nernst equation: assuming a membrane potential of $-46 \mathrm{mV}$, a charge of -2 , and an external sulfate concentration of $0.3 \mathrm{~mm}$ ). Since the sulfate level in normally grown cells of Chlorella fusca is about $1 \mathrm{~mm}$ [10], a 125-fold difference in concentration is achieved.

The existence of specific membrane-binding sites for sulfate is suggested by the inhibitory effect of the structural analogues chromate, selenate, sulfite and thiosulfate $[5,29,30]$. However, the sulfate permeases so far known differ in their affinity for molybdate and tungstate, both significantly larger anions than sulfate [29]. These two anions are not recognized by the sulfate permease of Chlorella fusca, whereas chromate and selenate strongly inhibit sulfate uptake. Obviously Chlorella fusca discriminates among anions of type $\mathrm{XO}_{4}{ }^{2-}$ by the size of the molecule itself, as observed in Monochrysis lutheri [29] and Fucus serratus [7]. In contrast to these results, Chlorella pyrenoidosa [5], Spirulina platensis [22] or fungi [30] cannot discriminate between sulfate and $\mathrm{MoO}_{4}{ }^{2-}$ or $\mathrm{WO}_{4}{ }^{2-}$.

Sulfite, thiosulfate and tetrathionate, which significantly inhibited sulfate uptake in Chlorella fusca, can also be seen as divalent analogues of sulfate. Especially thiosulfate was recognized as an alternative substrate of the sulfate permease in fungi [26, 30], in algae [5], and higher plants [27]. The monovalent anion methanesulfonate with structural relationship to thiosulfate was not inhibitory for sulfate uptake, demonstrating that the sulfate permease of Chlorella fusca has both size and charge recognition properties as known from other transport systems.

The inhibitory effect of cysteine and other mercaptides on sulfate uptake in Chlorella fusca may be explained as a chemical modification of the permease by $\mathrm{SH}$-groups, regulating its state of activity [27]. Methionine, another important product of sulfate metabolism, did not inhibit sulfate transport. However, in contrast to higher plant systems, neither cyst(e)ine nor methionine could be identified as the main regulator for sulfate uptake in Chlorella fusca since only the size of the sulfate pool correlated with the actual transport rate [10].

Sulfate-starved cultures were obtained either by sulfur depletion or by adding ethanesulfonate, which allows growth under conditions of sulfate starvation [10]. Enhanced sulfate uptake could be measured using both growth conditions stated above. A time period of 15 or $30 \mathrm{~min}$ was chosen for determining 
sulfate uptake, although later data showed that uptake was saturated within $7.5 \mathrm{~min}$. Since the turnover of the sulfate pool is low during this time period, the data concerning the sulfate pool size are correct, however the actual uptake rates measured under sulfur limitation might be higher. Thus further experiments are necessary using a rapid test system for uptake rates within 1 min or less to obtain results measured under true kinetic conditions under sulfur limitation.

Enhanced sulfate uptake in sulfate-starved cultures differed significantly from constitutive sulfate transport in Chlorella fusca: 1) Time kinetics was not linear but showed an initial rapid phase followed by a lower steady state rate. 2) Uptake was neither multiphasic nor conformed to simple Michaelis-Menten kinetics. At higher sulfate concentrations, uptake was significantly enhanced resulting in negative values for $K_{\mathrm{m}}$ and $V_{\max }$ (see [31]). 3) Enhanced sulfate uptake was hardly affected by the $\mathrm{pH}$ in the range of $\mathrm{pH}$ 5.0-9.0. 4) Enhanced sulfate uptake was little affected by temperature in the range from $18^{\circ} \mathrm{C}$ to $38^{\circ} \mathrm{C}$ with a $\mathrm{Q}_{10}$ of 1.2 and an activation energy of $15.1 \mathrm{~kJ} \mathrm{~mol}^{-1}$. The temperature optimum of $43^{\circ} \mathrm{C}$ was similar to that of unstarved cultures. 5) The

[1] B. Lass and C. I. Ullrich-Eberius, Planta 161, 53 (1984).

[2] G. J. Roomans, G. A. J. Kuypers, A. P. R. Theuvenet, and G. W. F. G. Borst-Pauwels, Biochim. Biophys. Acta 551, 197 (1979).

[3] S. Biedlingmaier and A. Schmidt, Physiol. Plant. 70, 688 (1987).

[4] C. Passera and G. Ferrari, Physiol. Plant. 35, 318 (1975).

[5] M. Vallée and R. Jeanjean, Biochim. Biophys. Acta 150, 607 (1968).

[6] M. Vallée and R. Jeanjean, Biochim. Biophys. Acta 150, 611 (1968).

[7] S. Coughlan, J. Exp. Bot. 28, 1207 (1977).

[8] P. Millard and L. V. Evans, Arch. Microbiol. 131, 165 (1982).

[9] C. I. Ullrich-Eberius, Planta 109, 161 (1973).

[10] S. Biedlingmaier, H.-P. Köst, and A. Schmidt, Planta 169, 518 (1986).

[11] I. Niedermeyer, S. Biedlingmaier, and A. Schmidt, Z. Naturforsch. 42 c, 530 (1987).

[12] S. Biedlingmaier and A. Schmidt, Biochim. Biophys. Acta 861, 95 (1986)

[13] R. Petterson and G. Knutsen, Arch. Microbiol. 96, 233 (1974)

[14] P. Nissen, Physiol. Plant. 24, 315 (1971).

[15] P. Nissen and Y. Nissen, Physiol. Plant. 57, 47 (1983).

[16] E. H. Ramos, L. C. de Bongioanni, and A. O. M. Stopani, Biochim. Biophys. Acta 559, 214 (1980).

[17] P. Nissen, Physiol. Plant. 28, 304 (1973).

[18] S. P. Singh and R. C. Paul, Biol. Plant. (Praha) 26, 29 (1984).
Arrhenius plot was biphasic with a bend at $38^{\circ} \mathrm{C}$. Above this temperature the activation energy increased tenfold to $163.0 \mathrm{~kJ} \mathrm{~mol}^{-1}$. According to Dixon and Webb [32] we interpret this type of Arrhenius plot as a dissociation of the sulfate transport system into subunits at a critical temperature, parallel to a high temperature coefficient.

These data clearly demonstrate differences between sulfate uptake in normal and sulfate-starved cultures of Chlorella fusca. Thus, the common methodical "trick" to use conditions of sulfur starvation for the characterization of sulfate uptake systems might result in data not comparable with sulfate transport systems in non-induced organisms. A higher specific activity of $\left[{ }^{35} \mathrm{~S}\right]$ sulfate should be used instead of physiological starvation with significant changes in uptake rate and mode, even if this results in a greater adsorption or radioactivity to the cell surface.

\section{Acknowledgements}

This work was supported by a grant from the Deutsche Forschungsgemeinschaft. We thank Prof. Dr. P. Nissen (Bergen) for calculating and plotting the kinetic data of sulfate uptake.

[19] P. D. Shargool and T. T. Ngo, Can. J. Bot. 53, 914 (1975).

[20] S. L. Jones and I. K. Smith, Plant Physiol. 67, 445 (1981).

[21] H. C. Utkilen, M. Heldal, and G. Knutsen, Plant Physiol. 38, 217 (1976).

[22] V. K. N. Menon and A. K. Varma, FEMS Microbiol. Lett. 13, 141 (1982).

[23] CRC Handbook Series in Nutrition and Food (M. Rechcigl, ed.), Section G: Diets, culture media, food supplements, Vol. III, Culture media for microorganisms and plants, p. 284, CRC Press, Ohio, Cleveland 1978.

[24] G. Knutsen, Physiol. Plant. 27, 300 (1972).

[25] S. Biedlingmaier and A. Schmidt, Z. Naturforsch. 42 c, 891 (1987).

[26] G. Bradfield, P. Somerfield, T. Meyn, M. Holby, D. Babcock, D. Bradley, and I. H. Segel, Plant Physiol. 46, 720 (1970).

[27] I. K. Smith, Plant Physiol. 58, 358 (1976).

[28] G. Langmüller and $\mathrm{H}$. Springer-Lederer, Planta 120, 189 (1974).

[29] E. Deane and R. W. O'Brien, Arch. Microbiol. 105, 295 (1975).

[30] J. W. Tweedie and I. H. Segel, Biochim. Biophys. Acta 196, 95 (1970).

[31] S. G. Jackson and E. L. McCandless, Can. J. Bot. 60, 162 (1982).

[32] M. Dixon and E. C. Webb, Enzymes, second edition, Longmans (1964). 